
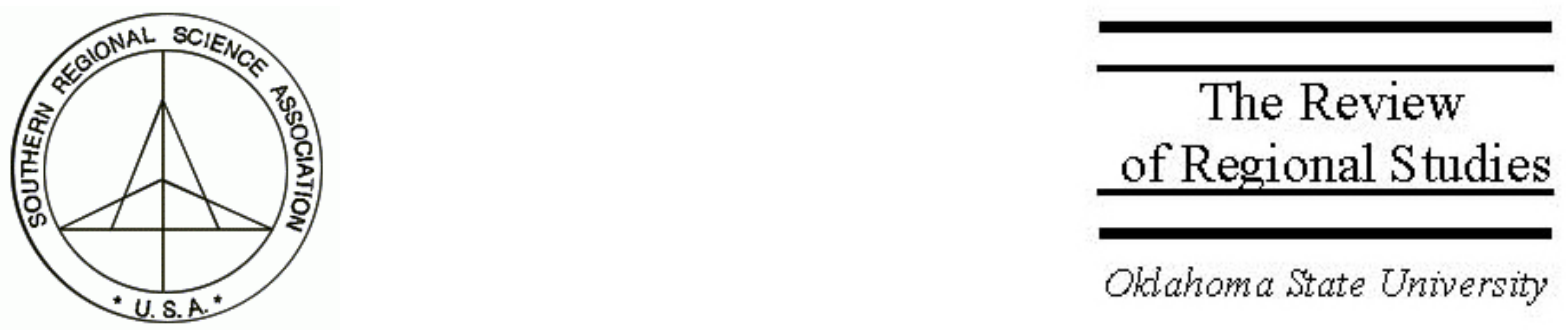

\title{
Reconsidering the Southern Black Belt ${ }^{*}$
}

\author{
Robert M. Gibbs \\ Economic Research Service, U.S. Department of Agriculture, 1800 M Street, NW, \\ Room S2079, Washington, DC 20036. email: rgibbs@ers.usda.gov
}

Presented as the presidential address at the annual meetings of the Southern Regional Science Association in Louisville, Kentucky, April 12, 2003

\begin{abstract}
The portion of the South known as the "Black Belt" lies at the heart of what was once the cottonand-tobacco plantation region and retains a large black population. Despite the Black Belt's high poverty rates and relatively slow economic growth, its large net loss of blacks to urban areas over the course of the twentieth century has effectively ended and more are now returning. Rural southern blacks still face a low-wage economy and their prospects are conditioned by a legacy of both southern agricultural paternalism and, due to interregional migration, inner-city decline. A number of writers have noted the importance of familial and community ties for returnees and express cautious optimism about their abilities to further erode the region's old social and economic barriers. More generally, anti-poverty strategies in the Black Belt, public and private, will be successful only insofar as they are sensitive to the social exclusion that continues to restrict the full participation of blacks in rural southern labor markets and civil society.
\end{abstract}

\footnotetext{
* The author would like to thank Calvin Beale, Carolyn Rogers, Carmen Sanchez, and Leslie Whitener for their helpful comments on an earlier draft of this article.
} 


\section{INTRODUCTION}

In the closing decades of the twentieth century, the rural South witnessed an historic demographic event. The great net migration of blacks to urban areas that had begun in earnest during World War I came to an end. By the 1990s, the region was absorbing more migrants from the North, Midwest, and West than it lost. In her book Call to Home: African Americans Reclaim the Rural South (1996), Carol Stack describes the lives of people who had left to find better jobs and a less oppressive social climate but eventually felt the pull of their old regional and family ties. She documents their ambivalence about life back in the rural South. They struggled to find a place in a world often very different from the one they left in the city and not nearly different enough from the world known to their forebears.

The majority of black southern migrants returned to the heart of the row-crop plantation region, which today consists of a few well-defined clusters. The most famous of these in the mind of the American public is the Mississippi-Yazoo Delta. One of greater area and population is a strip of land between the Delta and the Chesapeake Bay that has come to be known as the Black Belt and includes about 200 contiguous counties in which blacks make up at least 25 percent of the population. ${ }^{1}$

Named originally for the dark, loamy soils of central Alabama and only later for its racial composition, the Black Belt to this day conjures images of severe material deprivation, oppression, and social exclusion. These images belie the efforts of many in and out of the region to forge a more prosperous and egalitarian society. It is true, though, that the region continues to challenge researchers and policy makers interested in ameliorating the lasting effects of a troubled social and economic history. One of the most enduring of these effects, and the subject of my address, is the very high poverty of the great majority of rural Black Belt counties. Despite a decade of robust national growth, the traces of prosperity are still all too scarce in this particular corner of the Sunbelt.

What makes the Black Belt attractive to one-time outmigrants and their offspring? If its realities are now less nurturing to these returnees than they seemed in the Bronx or Southside Chicago, what can be done to make them more so? What policy prescriptions might be most effective in fighting poverty in a place where the classical model of wage-maximization cannot fully account for human behavior and where racial economic equality has yet to arrive? My intent is to relate the story that I believe the spate of recent data analysis and scholarship tells us regarding these questions.

Underlying this story is a familiar theme. As we take a look at the current state of the Black Belt, it's best to keep in mind the words of Gavin Stevens in Faulkner's Requiem for a Nun: "The past is never dead. It's not even past." Granted, the region hasn't fully shaken the less appealing aspects of an earlier era. Less obvious, though of greater import, is that recent national policy debates about poverty, work, and race at times echo the political and cultural discourse of

\footnotetext{
${ }^{1}$ The "rural" counties described here all lie outside metropolitan areas as designated by the federal government based on the 1990 Census. Many of them in fact have an "urban" population component, usually one or more towns with a population of at least 2,500 .
} 
an earlier Black Belt. Like the migrants from America's inner cities, the national policies most likely to make a difference in the region today have deep roots in its history.

\section{THE CONTINUING PROBLEM OF HIGH POVERTY}

The full arc of black poverty stretches well over a thousand miles from Texas to Virginia. My remarks and observations in the remainder of the presentation focus on the counties east of the Mississippi Delta, in a portion of the arc that has been relatively underexamined. The Black Belt today, a region of over five million people, is the remnant of a much larger plantation South that has receded over the course of the twentieth century. Over its length, there has been marked demographic stability since the 1970s. Blacks' share of the population has dropped just over a percentage point since 1980, and the region remained 40 percent black as of 2000 .

Black Belt counties are far from homogeneous in their geography and history. They include both the lower reaches of Pine Mountain, Georgia, as well as the low-lying Virginia tobacco lands whose river currents are affected by the ocean tides. They were settled over a period of several centuries, from the early 1600s in Virginia to as late as the 1840s in parts of Georgia and Alabama.

Their economies exhibit a good deal of variation. Counties in the eastern portion rely more heavily on services but have high wages by southern standards. The western portion, particularly in Alabama and Mississippi, is more heavily invested in what remains of that region's low-skill manufacturing, while the steep decline in the 1990s in its still-sizable farming base is reminiscent of what happened elsewhere 30 years ago.

A constant along most of this 1,000-mile arc is its high poverty rates. The 2000 Census, recorded during the most recent year of robust economic growth in this country and a trough for poverty nationally, shows the average poverty rate in the Black Belt to be 22 percent, against a national rate of 13 percent. The salient feature, however, is that one in three blacks here is poor. Not so long ago, a discussion about poverty in the Deep South would have been unthinkable without a corresponding discussion of race. A recent report on poverty in the Black Belt published by the Carl Vinson Institute of Government at the University of Georgia (2002) is representative of a recent shift in emphasis. The authors explicitly discount the poverty-race relationship by stating that ". . . race is neither a symptom nor a cause of poverty." I find this de-emphasis understandable in a sense. Too often in the past linking race and poverty has been a way of putting the burden of change on those who have experienced the most deprivation and who are often not well-equipped to effect change without external support.

Nonetheless such a view, taken outside a narrow context, runs the risk of missing the tightly woven relationships of race, economic development, and well being. One cannot disregard the essential fact that being poor and black are nearly synonymous in scores of small towns and villages in the region. The gap between black and white poverty is quite large; 2000 Census numbers show a black poverty rate three times that of white poverty in the Black Belt. In fact, white poverty is lower here than in rural America as a whole. Moreover, consider that the decline in poverty rates has been quite small in the aggregate since 1980, after a steep drop during the previous 20 years. Consider, too, other outcomes associated with high poverty. In the 
1990s the rate of diabetes and heart disease in the region was 17 percent above the national average, the rate of low birth weight babies was 25 percent above the national average, and the proportion of families living in mobile homes was three times the national average (Carl Vinson Institute 2002). The Black Belt's poor score on each of these is driven largely by higher rates for blacks.

\section{POVERTY AND HUMAN CAPITAL}

The region has been characterized typically as one of low-wage, low-skill jobs, with blacks typically at the lowest rungs of the jobs ladder. Its job growth has chronically lagged growth in the rest of the Sunbelt, its industry mix is undiversified, its public services are often underfunded, and many of its schools turn out students less prepared than students in other parts of the country (Falk and Lyson 1988, Greenberg and Teixeira 1998).

A brief sketch of change in the 1990s gives an only slightly less pessimistic view of the Black Belt economy. Population and job growth were lower than in the rest of the South, and unemployment rates remained well above the national average. Earnings growth kept pace with the South as a whole, but labor force participation rates for both blacks and whites, men and women, fell further in the Black Belt than in any other rural region, including the Delta. Part of the increase in average earnings came at the expense of those who would have worked in lowwage, low-skill jobs but now find themselves out of the labor force altogether.

There is near-consensus that very low levels of human capital are the underlying limiting factor in the region's growth and development. Actually, the share of adults who have completed high school is comparable to that in the rest of the rural South, but it is highly uneven racially. White completion rates in the Black Belt are the highest in the rural South (over 90 percent), but less than 60 percent of black adults have a high school diploma. Only one in 14 has a college degree. Even the human capital exchange from migration flows ends up as a net loss: inmigrants have lower education levels and higher poverty than outmigrants (Fuguitt, Fulton, and Beale 2001).

The Black Belt's human capital problems are reflected in another key measure of economic health. Although the region's earnings on average are close to the overall rural average, and manufacturing earnings are above average, labor force participation rates among blacks are low-52 percent for black men in 2000, for example, compared with 68 percent for white men. These, combined with very high rates of female-headed households, suggest a vital disconnect between a significant share of the working-age population and the labor market in the rural South (Beale 2003).

In her latest book, Worlds Apart (1999), Cynthia Duncan examines the social and economic separation of blacks and whites in the Delta. Her observations are applicable here as well. She views low human capital not as the first principle of lagging economic development. Rather it is a key outcome of a milieu in which the poor lack both the supports that enable them to participate fully in the working world and the access to the financial and social ties available to the middle class. The lack of support and access dampens human capital acquisition and lowers the returns. The result is a perpetuation of economic dependence, of an inability to sustain 
oneself through one's own labor. It is hard to see how it could be otherwise given dependency's dual parentage: a distant agrarian past and the more recent experience of urban enclaves with their joblessness, social isolation, and receptiveness to public assistance.

\section{LEGACIES OF A SOUTHERN AGRARIAN PAST}

At first blush, it is profoundly ironic that blacks should return to the Black Belt in part to escape economic dependence. Most rural blacks who moved north and west during the Great Migration had in one way or another experienced the dependency of agricultural paternalism, a system that Lee Alston and Joseph Ferrie (1999) describe as essentially a contract that, in theory at least, delivered significant benefits to both planter and workers. Based primarily on farm tenancy, this system bound employer and worker through the provision of housing, medical care, and other in-kind services along with cash wages. At its heart, it guaranteed a stable and adequate labor supply to the planter. Though restricted by the directives of the planter, workers in return received some measure of economic stability, including a social safety net, access to financial capital, and physical protection in an often-violent society. In this environment, the rural elite were compelled to oppose in the strongest terms any attempts to institute governmentrun programs of social welfare, whether at the local, state, or federal level, in order to preserve the value of in-kind transfers.

Rural industrialization proceeded slowly in the Black Belt during these years. Although planters had an interest in preventing competition for labor from factory owners, they also saw the benefit of having at least limited alternative employment opportunities for a cyclical workforce. Manufacturers benefited from the large pool of unskilled labor, the low wages, and the absence of unions. Diversification kept wages low because the local workforce was able to piece together a living through a combination of farm, factory, and informal activities (Cobb 1984).

Paternalism became increasingly difficult to sustain in the 1940s as the economic expansion of World War II created job opportunities for rural blacks in urban factories. There was often no economically viable inducement that could equal the value of relatively well-paying jobs, better services, and greater freedom in northern cities.

In the 1950s, the modern civil rights movement focused national attention on methods of social control, particularly threats of physical violence. Cotton harvesting was mechanized. Labor demand went into a free fall and outmigration rose sharply - between 1945 and 1965, the southern farm population fell from 16 to 5 million. The incentives for planters to maintain inkind provisions disappeared. But so did at least one rationale for opposing welfare.

The other half of the story, of course, is that manufacturing jobs in the north became a beacon for millions of southern black farm workers who left urban centers, leading eventually, in William Julius Wilson's thesis of inner-city decline (1996), to the destruction of nuclear families and civic life in the last quarter of the century. Along with a scarcity of jobs in the formal sector grew the lure of the informal economy and the need to accept government assistance. 
Clearly most black migrants out of the rural South were not a part of this decline. A long debate in the urban economics literature appears to have been won by those who argue that rural southern black migrants largely escaped the growing ills of inner city life and joined the middle class. ${ }^{2}$ Those who did not, however, found they had traded one form of dependency for another. History, again, did not work to their advantage. The social and economic disconnection they experienced often fostered a sense of dislocation and a degradation of social and familial networks (Lemann 1991).

I would argue that the Black Belt contributed more than just its share of the 7 million black migrants who left the region between World War I and the last days of plantation agriculture. The experiences of both blacks and whites there helped to define the national discourse on race, poverty, and the role of government up to the present day. To paraphrase James Cobb in The Most Southern Place on Earth (1992), the recent debates on these issues in Washington reflect in large degree southern blacks' and whites' success in alternately directing and containing the conversation.

The Personal Responsibility and Work Opportunity Reconciliation Act of 1996 exemplifies the workings of these lines of force. Its aims are both an outgrowth of traditional views of government assistance once held by ruling southern whites and a contemporary response to that tradition. Note, for example, how the notion of economic dependence was used by opponents of AFDC - ironically, given the South's history - to end broad access to public assistance. But welfare reform's most promising elements implicitly grapple with some of the central issues of Black Belt poverty. Many who supported reform touted the philosophical shift to a system of work supports as a way to help bring the poor out of the margins and closer to the connected center of American economic life. ${ }^{3}$

\section{A DIFFERENT VISION FOR THE FUTURE}

The migrants in Call to Home had already learned the need for connection. They returned to the South to find an only partially transformed society still divided along racial lines, with limited economic possibilities. The Black Belt is attractive in part because one can live on limited income much more easily than in the city (Nord 1998). But their experience of moving from city to small town and country life can also be seen literally and metaphorically as a search for attachment with a wider net of family and society. Often return migrants moved in with parents or near siblings. They reestablished old childhood acquaintances. Some chose to make a difference in the larger community outside what in earlier times would have been their prescribed sphere.

In an earlier Black Belt, their choice would have been either to remain in a place where they did not control the rules of the game or to live elsewhere. What is needed now is not a return to these paths - not to the social relations that existed in pre-movement days, nor to a set of government programs that seemed resigned to a two-tiered society. The path that the most

\footnotetext{
2 Tolnay, Vesselinov, and Crowder (1999) provides a recent, brief review of this literature.

${ }^{3}$ The New World of Welfare (2001), edited by Rebecca M. Blank and Ron Haskins, provides a view of all sides of the debate over the origins and implications of the 1996 legislation.
} 
ambitious of these returnees, and increasingly of nonmigrants as well, are following is one that calls for a different vision of people's relationship to the labor market and to civil society.

I am enough of an optimist to believe that the best elements of recent public policy are in accord with that vision, particularly those that encourage a strong labor force attachment. That includes both direct supports for work and indirect supports for sustaining and strengthening individuals and families. It recognizes the primacy of market forces and the limitations of income maintenance programs, yet may demand not less but more collective action.

Recent policy has implicitly hewed to these principles: the expansion of the Earned Income Tax Credit is targeted at workers earning very low wages in order to make work pay. Welfare reform placed a new, if highly uneven, emphasis on providing work supports. What both of these have in common is that they address low income by supporting economic independence rather than providing basic providence. With its high poverty and low asset levels, its family structures that make full-time, full-year work more difficult, and local governments with limited capability and will to provide support services, the Black Belt would benefit disproportionately from programs that remove the lack of childcare and transportation as obstacles and motivate work by raising income above the poverty line. Ultimately, this may mean rethinking systems that follow these practices to the letter but not in the spirit, for example, those that provide childcare of marginal quality and commutes that take half as long as the daily shift (Henry and Lewis 2001).

We are also beginning to realize the extent to which indirect support is needed as well. The poor in the Black Belt, as elsewhere, suffer disproportionately from work-limiting disabilities and health problems. They are more likely to be victims of crime and are more likely to be in family or neighborhood conditions where physical safety can impede their ability to work. Crime, in particular, is often modeled as a function of income, but there is growing recognition of crime's role in perpetuating poverty, as in the research efforts underway at the Center for Poverty Research at the University of Kentucky.

Education forms the strongest, most durable bond to the social and economic mainstream. Human capital investment is still the core of any viable Black Belt development strategy. A "work first" philosophy may jump start labor force attachment. But the limitations are real and quite stark for high school dropouts and even for high school graduates with additional work barriers. Fewer and fewer employers, after all, particularly in key sectors like manufacturing, are looking merely for large pools of unskilled labor in rural areas (McGranahan 2001, Barkley 1995). A discussion of the need to reinvent public education in the Black Belt is long overdue. We know now as we did not know even a decade ago how much school quality matters in both student achievement and economic growth (Barkley, Henry, and Bao 1998, Gibbs, Swaim, and Teixeira 1998). Yet there is so far very little solid research that applies these findings to specific conditions in the region, such as the high levels of de facto segregation and the implications for black-white schooling disparities.

Duncan makes the crucial point that pursuing a good education goes hand in hand with knowing how. She likens the ways in which we leverage the information and knowledge we acquire in order to propel ourselves on to successful work lives to a "cultural toolbox." The poor 
have cultural toolboxes with fewer tools that are advantageous in getting a college education or a good job. Without the often-serendipitous intervention of a guiding hand, many will never even know what their objectives could have been, much less how to attain them. One aspect of the cultural toolbox is the strength of our social bonds and information networks, our social capital.

Economists have begun to acknowledge the importance of social capital for well being in their published research. Duncan shows, though, that conventional measures of social capital have little relevance for poor blacks in the rural South — not because they lack social networks of trust and information, but because they are excluded from networks that enable economic selfsufficiency and wage progression. Putnam's (1993) notion of social capital, which tends to guide economists' work, largely ignores these negative effects of social capital in a divided community. We should take care, then, that our measures of social capital account for such small-scale divisions. Some of the earlier work in social capital, especially by James Coleman (1988) as well as Bourdieu (1986), may serve as a useful corrective here.

Ultimately, however, the implication is that the racial inequality that helps perpetuate poverty in the Black Belt will change when both races share in making the rules of engagement. Not all of the developments in Worlds Apart lead us to pessimism. Duncan also writes of a new generation of blacks working for equality within the system-neither accommodationist nor revolutionary, this generation is, I believe, very much from the same cloth as Stack's returnees in North Carolina. One of our tasks is to find ways of understanding and measuring the impact of their efforts on social capital investment in Black Belt communities.

Moreover, the Black Belt is not completely without locational advantages compare with many other regional concentrations of poverty. One advantage is its proximity to major urban centers. Its outer edges lie within the commuting field of four metropolitan areas of over a million people. The Belt is also distinctive for being punctuated by a number of smaller but regionally important employment centers from Montgomery to Richmond. A few of its counties have already benefited from this proximity - Hale county in western Alabama, just south of metropolitan Tuscaloosa, saw its black poverty rate drop 26 percent in the 1990s due in part to the opening of a Mercedes plant in nearby Vance.

Most counties in the Black Belt, however, will have to come to terms with their locational disadvantages and their sparse set of physical and cultural amenities. Most of the poor will have to come to terms at least for the foreseeable future with the social disconnection, the secondary importance placed on universal education, and the inadequacy of public services. My aim here has been far more modest than proposing a rigorous research agenda for identifying effective methods of poverty reduction in rural areas that have a legacy of racial division. My task rather has been to refocus attention on a specific problem in regional development that has, with notable exceptions, ${ }^{4}$ received scant recent attention and that I believe will require us to broaden our disciplinary scope.

I began working on this address with a sense of pessimism about the prospects for economic development in places like the Black Belt. I have come to recognize that just as there are still villages and countryside in the Black Belt where being black and being poor are closely

\footnotetext{
${ }^{4}$ See, for example, Levernier, Partridge, and Rickman (2000).
} 
associated, there are other places there where differences with the rest of America have diminished to a remarkable degree. And the return of children of oppressed farmers is a hopeful sign that a region that has often reluctantly accepted change may one day embrace it.

\section{REFERENCES}

Alston, L., and J. Ferrie, 1999. Southern Paternalism and the American Welfare State. Cambridge University Press: Cambridge.

Barkley, D.L., 1995. "The Economics of Change in Rural America," American Journal of Agricultural Economics 77, 1252-58.

, M. Henry, and S. Bao, 1998. "The Role of Local School Quality in Rural Employment and Population Growth," The Review of Regional Studies 28(1), 81-102.

Beale, C.L., 2003. "The Ethno/Racial Context of Poverty in Rural and Small Town America," Poverty and Race 12(2), Newsletter of the Poverty and Race Research Action Council.

Blank, R.M., and R. Haskins (eds.), 2001. The New World of Welfare. Brookings Institution: Washington, D.C.

Bourdieu, P., 1986. "The Forms of Capital," in John Richardson (ed.), Handbook of Theory and Research for the Sociology of Education. Greenwood Press: New York, 241-58.

Carl Vinson Institute of Government, University of Georgia, 2002. It's a Matter of Wealth: Dismantling Persistent Poverty in the Southeastern United States. Project report from the Study on Persistent Poverty in the South.

Cobb, J.C., 1984. Industrialization and Southern Society, 1877-1984. University of Kentucky Press: Lexington.

, 1992. The Most Southern Place on Earth: The Mississippi Delta and the Roots of Regional Identity. Oxford University Press: Oxford.

Coleman, J., 1988. "Social Capital in the Creation of Human Capital," American Journal of Sociology 94, S95-S120.

Duncan, C.M., 1999. Worlds Apart: Why Poverty Persists in Rural America. Yale University Press: New Haven.

Falk, W.W., and T.A. Lyson, 1988. High Tech, Low Tech, No Tech. State University of New York Press: Albany. 
Fuguitt, G.V., J.A. Fulton, and C.L. Beale, 2001. The Shifting Patterns of Black Migration From and Into the Nonmetropolitan South, 1965-95. Economic Research Service, U.S. Department of Agriculture, Rural Development Research Report No. 93.

Gibbs, R.M., P.L. Swaim, and R. Teixeira (eds.), 1998. Rural Education and Training in the New Economy: The Myth of the Rural Skills Gap. Iowa State University Press: Ames, IA.

Greenberg, E.J., and R. Teixeira, 1998. "Educational Achievement in Rural Schools," in R.M. Gibbs, P.L. Swaim, and R. Teixeira (eds.), Rural Education and Training in the New Economy: The Myth of the Rural Skills Gap. Iowa State University Press: Ames, IA.

Henry, M.S., and W. Lewis, 2001. "Welfare Reform: Remedy for Persistent Poverty in the South?" Rural America 15(4), 59-67.

Lemann, N., 1991. The Promised Land: The Great Black Migration and How it Changed America. Alfred A. Knopf: New York.

Levernier, W., M.D. Partridge, and D.S. Rickman, 2000. "The Causes of Regional Variations in U.S. Poverty: A Cross-County Analysis," Journal of Regional Science 40(3), 473-497.

McGranahan D.A., 2001. "New Economy Manufacturing Meets Old Economy Education Policies in the Rural South," Rural America 15(4), 19-27.

Nord, M., 1998. "Poor People on the Move: County-to-County Migration and the Spatial Concentration of Poverty," Journal of Regional Science 38(2), 329-51.

Putnam, R., 1993. Making Democracy Work: Civic Traditions in Modern Italy. Princeton University Press: Princeton.

Stack, C., 1996. Call to Home: African-Americans Reclaim the Rural South. Basic Books: New York.

Tolnay, S.E., E. Vesselinov, and K.D. Crowder, 1999. "The Collective Impact of Southern Migrants on the Economic Well-Being of Northern-Born Black Males, 1970," Social Science Quarterly 80(4), 666-686.

Wilson, W.J., 1996. When Work Disappears: The World of the New Urban Poor. Alfred A. Knopf: New York. 